\title{
EVALUASI GEOMETRIK - KINERJA DAN PERKERASAN LENTUR JALAN RAYA BALURAN KM 248 - KM 250 KABUPATEN SITUBONDO
}

\author{
Muh. Nizar Junaidi Ainur Rofieq ${ }^{1}$,Rofi Budi Hamduwibawa ${ }^{2}$, Adhitya Surya Manggala ${ }^{3}$ \\ Program Studi Teknik Sipil, Fakultas Teknik, Universitas Muhammadiyah Jember ${ }^{1}$ \\ Jalan Karimata 49, Jember 68172, Indonesia \\ nizarjunaidi1997@gmail.com \\ Program Studi Teknik Sipil, Fakultas Teknik, Universitas Muhammadiyah Jember ${ }^{2}$ \\ Jalan Karimata 49, Jember 68172, Indonesia \\ Program Studi Teknik Sipil, Fakultas Teknik, Universitas Muhammadiyah Jember ${ }^{3}$ \\ Jalan Karimata 49, Jember 68172, Indonesia
}

\begin{abstract}
The importance of improving land transportation infrastructure which can support the smooth and equitable development, therefore roads are an important facility for humans to reach an area that they want to reach. The highway is a track that aims to pass traffic from one place to another. The north coast highway (Pantura) is a highway that falls within the criteria of a road which is heavily passed by heavy vehicles because, Baluran highway is a connecting road between Situbondo district and Banyuwangi district. Baluran road conditions are winding and there are slopes (vertical). With a width of road $=7$ meters, this highway is passed by heavy vehicles. This solid volume of vehicles results in overloading of the road resulting in frequent damage to the road body. In addition, sharp curves (horizontal curves) and slope and grade slopes (vertical curves) coupled with conditions around the shoulders of trees which also provide poor visibility.

Considering the above conditions (geometric and flexible pavement) on the Baluran highway, reevaluation or analysis of the length of the curvature (horizontal and vertical curves) is required, in addition to the frequent damage to the road body, an evaluation of the thickness of the flexible pavement is needed.
\end{abstract}

Keywords: Geometric, Overloading, Flexible Pavement.

\section{PENDAHULUAN}

Kondisi medan jalan raya Baluran yaitu berliku dan terdapat kelandaian (vertikal). Dengan lebar jalan $=7$ meter, jalan raya ini banyak dilewati kendaraan berat. Adapun contoh kendaraan berat seperti kendaraan pribadi, Bus, Truk 2 as, Truk 3 as, Truk gandengan dan Truk semi/trailer. Volume kendaraan yang padat ini mengakibatkan terjadinya pembebanan pada jalan tersebut. Dengan pembebanan (tonase) yang overloading ini mengakibatkan seringnya kerusakan pada badan jalan.

Disamping itu, dengan tikungan-tikungan yang tajam (curve horisontal) dan kelandaian tanjakan dan turunan (curve vertikal) dapat memberi jarak pandang pengemudi yang kurang baik.

\section{RUMUSAN MASALAH}

Rumusan rmasalahan dalam penelitian ini adalah:

1. Bagaimana kinerja jalan raya Baluran KM 248 - 250 Kabupaten Situbondo saat ini?

2. Bagaimana perencanaan tebal perkerasan dengan metode Bina Marga 2013 dan perbandingan dengan metode Bina Marga 1987 untuk umur rencana 20 Tahun?

3. Bagaimana evaluasi geometrik jalan raya Baluran KM 248 - 250 Kabupaten Situbondo saat ini?

4. Bagaimana kelengkapan inventaris jalan pada jalan raya Baluran KM 248 - 250 Kabupaten Situbondo?

\section{TUJUAN PENELITIAN}

Tujuan penelitian ini sebagai berikut :

1. Menganalisa kinerja jalan raya Baluran KM 248 - 250 Kabupaten Situbondo saat ini. 
2. Menganalisa perencanaan tebal perkerasan lentur menggunakan metode Bina Marga 2013 dan perbandingan dengan metode Bina Marga 1987.

3. Menganalisa geometrik jalur jalan raya Baluran KM 248 - 250 Kabupaten Situbondo dengan metode lingkaran sederhana (Full circle) saat ini.

4. Menganalisa kelengkapan inventaris jalan pada jalan raya Baluran KM $248-250$ Kabupaten Situbondo saat ini.

\section{BATASAN MASALAH}

Batasan masalah pada penelitian ini adalah:

1. Penelitian ini dilaksanakan di jalan raya Baluran KM 248 - 250 Kabupaten Situbondo.

2. Mengevaluasi kinerja jalan raya Baluran KM 248 - 250 Kabupaten Situbondo.

3. Mengevaluasi perencanaan tebal perkerasan lentur dengan metode Bina Marga 2013 pada jalan raya Baluran KM 248 - 250 Kabupaten Situbondo.

4. Mengevaluasi geometrik jalan raya Baluran KM 248 - 250 Kabupaten Situbondo.

5. Mengevaluasi kelengkapan inventaris jalan pada jalan raya Baluran KM 248 - 250 Kabupaten Situbondo.

6. Pengambilan data geometrik dan volume kendaraan :

a. Data setting dan stationing atau pengidentifikasian lokasi penelitian.

b. Data beda tinggi dan jarak/panjang $(\mathrm{H})$.

c. Data sudut Azimuth $(\psi)$ dan sudut horisontal $(\beta)$.

d. Data situasi lokasi penelitian.

e. Data volume kendaraan didapat dari pengamatan langsung (primer) atau dari Dinas Pekerjaan Umum (sekunder), dan

f. Tidak menghitung anggaran biaya (RAB).

\section{LOKASI PENELITIAN}

Lokasi penelitian dilaksanakan di Jalan Raya Baluran KM 248 - 250 Kabupaten Situbondo, atau 248 sampai 250 kilometer arah timur Surabaya. Lokasi penelitian ini merupakan jalan raya dengan kelas I yang menghubungkan Kabupaten Situbondo dan Banyuwangi, serta merupakan jalan penghubung antar provinsi (Jawa-Bali).

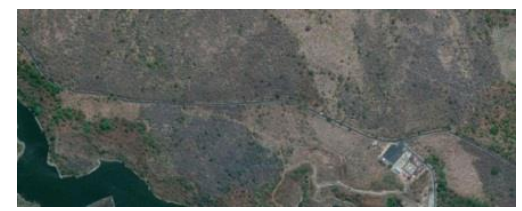

Gambar 1. Lokasi Penelitian Tugas Akhir

\section{TAHAPAN PENELITIAN}

Berikut ini adalah diagram alur untuk tahapan penelitian.

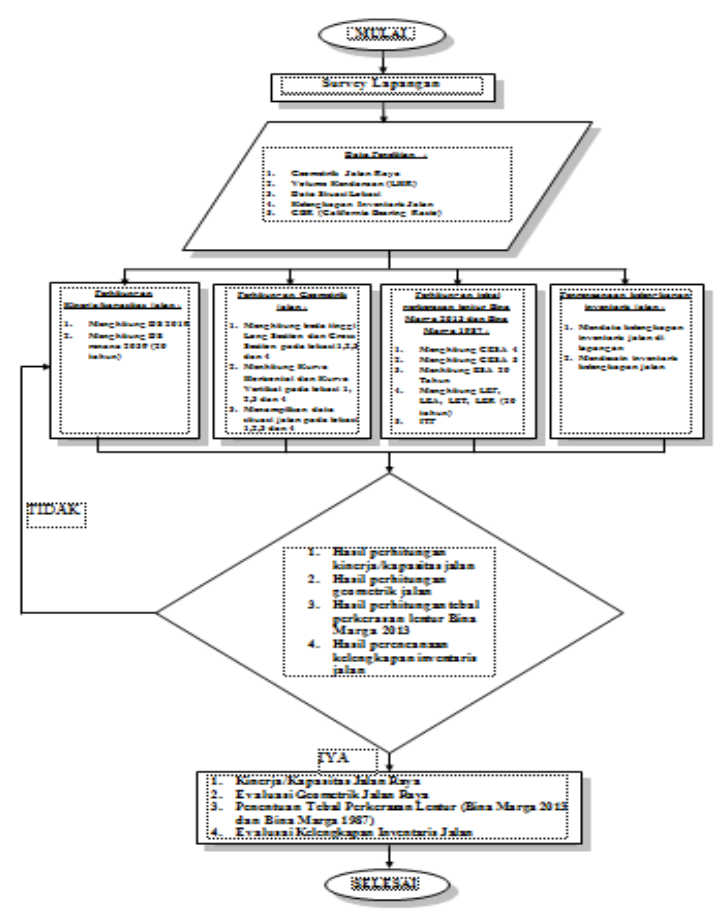

Gambar 2. Diagram Alir Penelitian

\section{HASIL DAN PEMBAHASAN}

\section{DERAJAT KEJENUHAN (DS) \\ PERHITUNGAN DS 2019}

\begin{tabular}{|c|c|c|c|c|c|c|c|c|}
\hline \multirow[t]{2}{*}{ Arah } & \multirow{2}{*}{$\begin{array}{l}\text { Pukul } \\
\text { (WIB) }\end{array}$} & \multirow[t]{2}{*}{$\begin{array}{l}\text { Sepeda } \\
\text { motor, } \\
\text { roda 3, } \\
\text { vespa }\end{array}$} & \multirow[t]{2}{*}{$\begin{array}{c}\text { Mobil } \\
\text { pribadi, } \\
\text { mobil } \\
\text { hantaran, } \\
\text { pick up, } \\
\text { mobil } \\
\text { box. }\end{array}$} & \multirow[t]{2}{*}{$\begin{array}{c}\begin{array}{c}\text { Bus, Truk 2 } \\
\text { as, Truk 3 } \\
\text { as, Truk } \\
\text { Gandengan, } \\
\text { semi/trailer }\end{array} \\
\text { HV } \\
\end{array}$} & \multicolumn{3}{|c|}{ Q SMP } & \multirow[t]{2}{*}{$\begin{array}{c}\text { Total Q } \\
\text { SMP }\end{array}$} \\
\hline & & & & & MC & LV & HV & \\
\hline $\begin{array}{l}\text { Situbondo- } \\
\text { Banyuwangi }\end{array}$ & $\begin{array}{c}\begin{array}{c}07.00- \\
08.00\end{array} \\
0.0\end{array}$ & 291 & 81 & 102 & 72,75 & 81 & 122,4 & 276,15 \\
\hline $\begin{array}{l}\text { itubondo- } \\
\text { Banyuwangi }\end{array}$ & $\begin{array}{l}07.00- \\
08.00 \\
\end{array}$ & 287 & 94 & 102 & 71,75 & 94 & 122,4 & 288,15 \\
\hline Total & & 578 & 175 & 204 & 144,5 & 175 & 244,8 & 564,3 \\
\hline
\end{tabular}

Untuk C smp = 3100 smp/jam dan Qsmp = $564,3 \mathrm{smp} / \mathrm{jam}$, sehingga didapat DS, sebagai berikut :

$$
\text { DS } \quad \begin{aligned}
& \mathrm{Q} / \mathrm{C} \ldots \ldots \ldots \\
& =564,3 / 3100 \\
& =0,182(\mathrm{~A})
\end{aligned}
$$

\section{PERHITUNGAN DS 2039}

\begin{tabular}{|c|c|c|c|c|}
\hline No & Jenis Kendaraan & $\begin{array}{c}\text { LHR } \\
\mathbf{2 0 3 9}\end{array}$ & $\begin{array}{c}\text { EMP } \\
\text { MKJI } \\
\mathbf{1 9 9 7}\end{array}$ & Q SMP \\
\hline 1 & MC & 1533,606 & 0,250 & 383,402 \\
\hline 2 & LV & 464,327 & 1,000 & 464,327 \\
\hline 3 & HV & 541,273 & 1,200 & 649,527 \\
\hline \multicolumn{2}{|c|}{ Total } & & & 1497,256 \\
\hline
\end{tabular}

Untuk C smp = 3100 smp/jam dan Qsmp = 1497,256 smp/jam, sehingga didapat DS, sebagai berikut :
DS
$=\mathbf{Q} / \mathrm{C}$ 


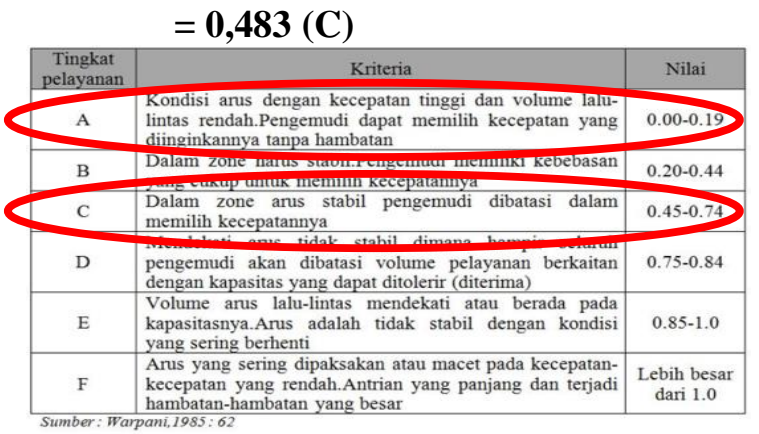

Kriteria \& Tingkat Pelayanan Jalan

\section{PERHITUNGAN \\ LENTUR \\ METODE BINA MARGA 2013}

Pada perhitungan perkerasan lentur dengan metode Bina Marga 2013, adapun langkahlangkahnya sebagai berikut :

a. Penetapan Umur Rencana (UR) $=20$ Tahun (direncanakan), sesuai Manual Perkerasan jalan No.02/M/BM/2013 halaman 9, yaitu lapisan lentur berbutir dan CTB

b. Klasifikasi Kendaraan dan Nilai VDF standar

\begin{tabular}{|l|r|}
\hline \multicolumn{1}{|c|}{ Jenis Kendaraan } & VDF4 \\
\hline $\begin{array}{l}\text { Kendaraan ringan, mobil } \\
\text { pribadi, pick up, mobil box, } \\
\text { mobil hantaran. }\end{array}$ & 0,3 \\
\hline Bus & 1,0 \\
\hline Truk 2 as & 0,8 \\
\hline Truk 3 as & 7,6 \\
\hline Truk Gandengan, semi/trailer & 13,6 \\
\hline
\end{tabular}

c. Menghitung ESA 20, dengan pertumbuhan lalu lintas (i) $=5 \%$ (untuk jalan Arteri dan perkotaan).

d. Menghitung faktor pengali pertumbuhan lalu lintas (R)

$\mathrm{i}=0,05(5 \%)$

UR $=20$ Tahun

$\mathrm{R}=(1+0.01 \mathrm{i})^{\mathrm{UR}}-1 /(0.01 \mathrm{i})$

$\mathrm{R}=(1+0,01 * 0,05)^{\wedge} 20-1$

$\mathrm{R}=\mathbf{2 0 , 0 9 5 2 8 5 6 1}$

e. Nilai Traffic Multiplier $(\mathrm{TM})=1,8-2,0$, disini diambil rata-rata yaitu 1,9

f. Menentukan Faktor Distribusi Lajur (DL) = 100\% dengan 1 lajur setiap arah

g. Perhitungan CESA4, CESA5 dan ESA 20 tahun

\begin{tabular}{|c|c|c|c|c|c|c|}
\hline No & Jenis Kendaraan & $\begin{array}{l}\text { LHR } \\
2019\end{array}$ & $\begin{array}{c}\mathrm{VDF} \\
4\end{array}$ & $\begin{array}{c}\text { ESA4 } \\
\text { VDF4"Ju } \\
\text { mlah } \\
\text { Kendaraan }\end{array}$ & $\begin{array}{c}\text { CESA4 } \\
\text { ESA4****365* } \\
\text { DL }\end{array}$ & $\begin{array}{c}\text { ESA5 } \\
\text { CESA4*TM }\end{array}$ \\
\hline 1 & $\begin{array}{l}\text { Kendaraan ringan, mobil } \\
\text { pribadi, pick up, mobil } \\
\text { box, mobil hantaran. }\end{array}$ & 2685 & 0,3 & 805,5 & 5908164,683 & 11225512,898 \\
\hline 2 & Bus & 907 & 1,0 & 907 & 6652644,776 & 12640025,075 \\
\hline 3 & Truk 2 as & 1639 & 0,7 & 1147,3 & 8415192,229 & \begin{tabular}{|l|l|}
159888655,236 \\
\end{tabular} \\
\hline 4 & & 684 & 7,6 & 5198,4 & 38129116,435 & \begin{tabular}{|l}
72445321,226 \\
\end{tabular} \\
\hline & $\begin{array}{l}\text { Truk Gandengan, } \\
\text { semi/trailer }\end{array}$ & 573 & 13.6 & 77928 & 57158467.711 & 108601088,652 \\
\hline & & & & & & \\
\hline
\end{tabular}

h. Pemilihan jenis perkerasaan pada ESA 20 tahun $=220900813,086$. Solusi desain pondasi jalan minimum. CBR Tanah Dasar
( $\geq 6 \%$ ), Tebal minimum peningkatan tanah dasar (Tidak Perlu Peningkatan).

i. Desain perkerasan lentur opsi biaya minimum pada ESA 20 tahun = 220900813,086. AC WC $50 \mathrm{~mm}$, AC BC $280 \mathrm{~mm}$, CTB $150 \mathrm{~mm}$, LPA kelas A 150 $\mathrm{mm}$.

j. Tebal lapis perkerasan

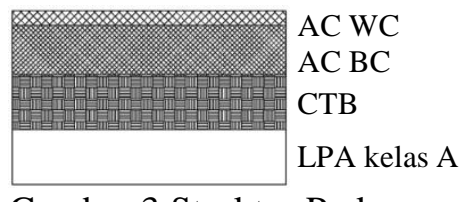

Gambar 3.Struktur Perkerasan

METODE BINA MARGA 1987

Angka Ekivalen (E), Dari Masing-masing Kendaraan

Berdasarkan Bina Marga 1987 untuk mencari nilai Ekivalen (E), dirumuskan sebagai berikut

\begin{tabular}{lc}
\hline \multicolumn{1}{c}{ Jenis Kendaraan } & \\
\hline $\begin{array}{l}\text { Angka Ekivalen } \\
(\mathbf{E})\end{array}$ \\
$\begin{array}{l}\text { Kendaraan ringan, mobil pribadi, } \\
\text { pick up, mobil box, mobil hantaran. }\end{array}$ & 0,0004 \\
Bus & \\
Truk 2 as & 0,1593 \\
Truk 3 as & 1,0648 \\
Truk Gandengan, semi/trailer & 1,0375 \\
\hline
\end{tabular}

Koefisien Distribusi Kendaraan (C) Jumlah 2 lajur 2 arah

Kendaraan ringan $=0,5$

Kendaraan berat $\quad=0,5$

Volume Kendaraan (LHR) Tahun 2019 dan Tahun 2039

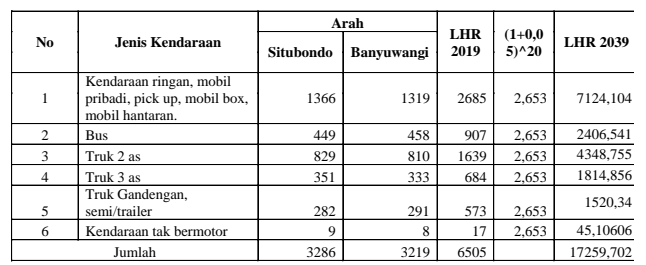

Lintas Ekivalen Permulaan $($ LEP $=2019)$

$\mathrm{LEP}=\sum \mathrm{LHR}_{\mathrm{j}} \times \mathrm{C}_{\mathrm{j}} \mathrm{x} \mathrm{E}_{\mathrm{j}}$

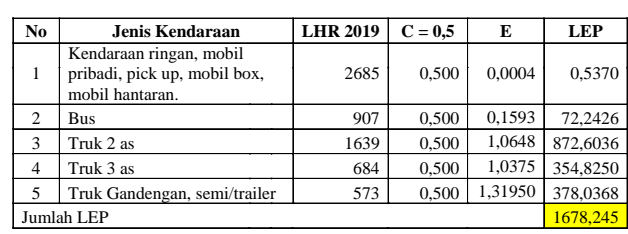

Lintas Ekivalen Akhir $($ LEA= 2039)

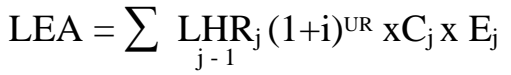




\begin{tabular}{|c|l|r|r|c|r|}
\hline No & \multicolumn{1}{|c|}{ Jenis Kendaraan } & LHR 2039 & $\mathbf{C = 0 , 5}$ & \multicolumn{1}{c|}{ E } & \multicolumn{1}{c|}{ LEA } \\
\hline 1 & $\begin{array}{l}\text { Kendaraan ringan, mobil } \\
\text { pribadi, pick up, mobil box, } \\
\text { mobil hantaran. }\end{array}$ & 7124,104 & 0,500 & 0,0004 & 1,4248 \\
\hline 2 & Bus & 2406,541 & 0,500 & 0,1593 & 191,6810 \\
\hline 3 & Truk 2 as & 4348,755 & 0,500 & 1,0648 & 2315,2771 \\
\hline 4 & Truk 3 as & 1814,856 & 0,500 & 1,0375 & 941,4564 \\
\hline 5 & Truk Gandengan, semi/trailer & 1520,340 & 0,500 & 1,3195 & 1003,0440 \\
\hline Jumlah LEA & & & 4452,883 \\
\hline
\end{tabular}

Lintas Ekivalen Tengah (LET) Untuk

Umur Rencana 20 Tahun

$$
\begin{aligned}
\text { LET } & =1 / 2 \times(\text { LEP }+ \text { LEA }) \ldots \ldots \ldots(6) \\
& =1 / 2 \times(1678,245+4452,883) \\
& =3065,564
\end{aligned}
$$

Lintas Ekivalen Rencana (LER)

LER $=$ LET $x$ FP.

$$
\begin{aligned}
(\mathrm{FP} & =\mathrm{UR} / 10) \\
& =3065,564 \times(20 / 10) \\
& =6131,128
\end{aligned}
$$

Daya Dukung Tanah (DDT

DDT ditentukan berdasarkan grafik korelasi antara nilai CBR tanah dasar $=27,3 \%$.

\section{Penentuan CBR Desain}

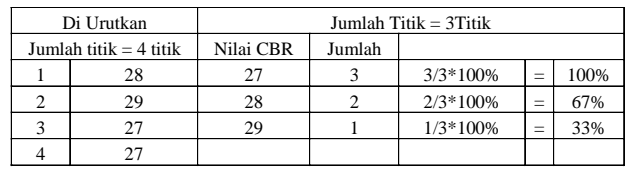

Dari data uji DCPT (Dynamic Cone Penetration Test) di dapat hasil pada tabel 4.25 dapat disimpulkan pada Grafik bahwa CBR segment yang diambil adalah $27,3 \%$.

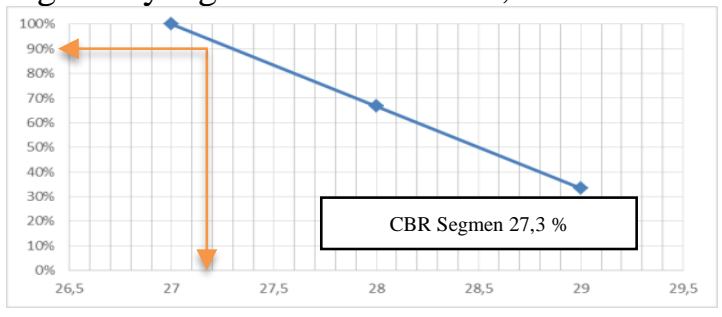

Grafik 1. CBR Segmen

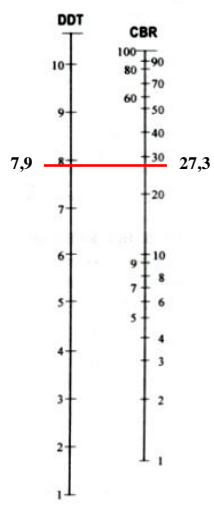

Grafik 2. Nilai Korelasi CBR dan DDT

Dengan LER $=6131,128$ ditentukan Indeks Pada Permukaan dengan Umur Rencana (IP) $=$ 2,0 - 2,5 dan Indeks Permukaan Awal Umur Rencana (IPo) $=\geq 4$.

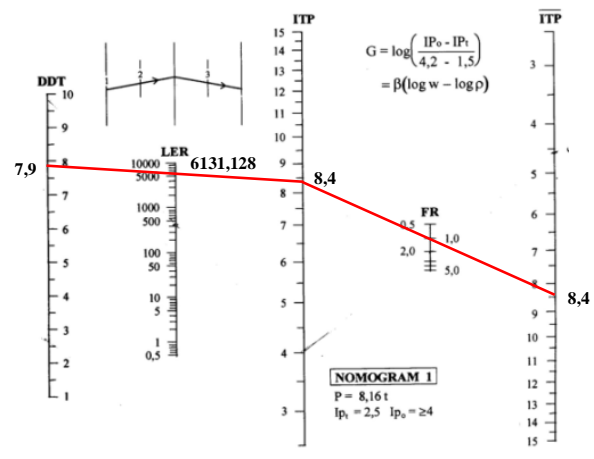

Grafik 3. Nomogram

Penentuan Indeks Tebal Perkerasan.

Pada Indeks Tebal Lapisan Perkerasan dinyatakan dengan rumus sebagai berikut :

ITP = a1.D1 + a2.D2 + a3.D3

Dimana :

$\mathrm{a} 1, \mathrm{a} 2, \mathrm{a} 3=$ Koefisien kekuatan relatif

D1,D2,D3 = Tebal masing - masing perkerasan

Maka Perhitungan Indeks Tebal Lapis Perkerasan sebagai berikut :

$$
\begin{aligned}
& \text { ITP }=\text { a1.D1 + a2.D2 + a3.D3 } \\
& 8,4=(0,40 \times 5)+(0,12 \times 20)+(0,11 \times \\
& \text { D3) } \\
& =2+2,4+(0,11 \times \text { D3 }) \\
& \text { D3 }=(8,4-4,4) / 0,11 \\
& \text { D3 }=4 / 0,11 \\
& =36,36 \mathrm{Cm}=40 \mathrm{Cm}
\end{aligned}
$$

Gambar 4. Lapisan Perkerasan

\section{GEOMETRIK JALAN \\ DATA JARAK DAN HITUNGAN}

Pengukuran jarak (meter) dilakukan secara langsung dilapangan menggunakan (Digital Measuring Wheel). data jarak dan hasil pengukuran sebagai berikut :

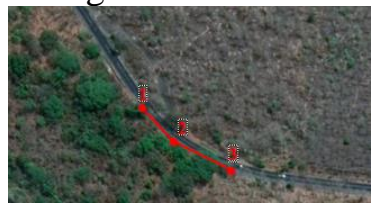

Gambar 5.Lokasi Penelitian I

\begin{tabular}{cc}
\hline Titik & $\begin{array}{c}\text { Panjang/Jarak } \\
\text { (Meter) }\end{array}$ \\
\hline $\mathbf{1 - 2}$ & 27,92 \\
$\mathbf{2 - 3}$ & 47,71 \\
Total & 75,63 \\
\hline
\end{tabular}




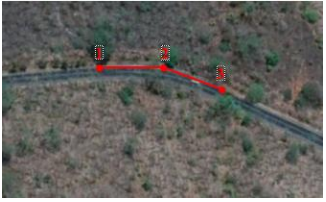

Gambar 6. Lokasi Penelitian II

\begin{tabular}{cc}
\hline Titik & $\begin{array}{c}\text { Panjang/Jarak } \\
\text { (Meter) }\end{array}$ \\
\hline $\mathbf{1 - 2}$ & 32,79 \\
$\mathbf{2 - 3}$ & 44,24 \\
Total & 77,03 \\
\hline
\end{tabular}

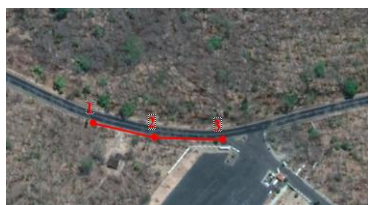

Gambar 7. Lokasi Penelitian III

\begin{tabular}{cc}
\hline Titik & $\begin{array}{c}\text { Panjang/Jarak } \\
\text { (Meter) }\end{array}$ \\
\hline $\mathbf{1 - 2}$ & 46 \\
$\mathbf{2 - 3}$ & 47,49 \\
Total & 93,49 \\
\hline
\end{tabular}

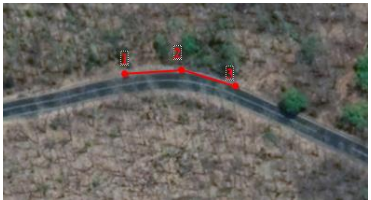

Gambar 8. Lokasi Penelitian IV

\begin{tabular}{cc}
\hline Titik & $\begin{array}{c}\text { Panjang/Jarak } \\
\text { (Meter) }\end{array}$ \\
\hline $\mathbf{1 - 2}$ & 28,38 \\
$\mathbf{2 - 3}$ & 29,52 \\
Total & 57,9 \\
\hline
\end{tabular}

\section{DATA BEDA TINGGI}

Pada pengukuran beda tinggi dengan alat ukur Total Station, dengan dua pengukuran, yaitu long section dan cross section.

Data Pengkuran Long Section dan Cross Section Lokasi Penelitian I :

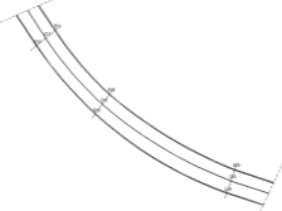

Detail Lokasi Penelitian I

\begin{tabular}{|c|c|c|c|c|}
\hline No. Titik & $\mathrm{X}$ & $\mathrm{Y}$ & $\mathrm{Z}$ & Notasi \\
\hline 63 & $-3,48$ & 132,054 & 6,478 & $\mathrm{C} 11$ \\
\hline 75 & 108,715 & 101,645 & 10,57 & $\mathrm{C} 13$ \\
\hline 85 & 68,377 & 123,578 & 7,675 & $\mathrm{C} 15$ \\
\hline
\end{tabular}

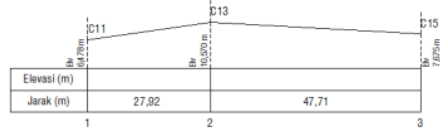

LONG SECTIONC11-C15

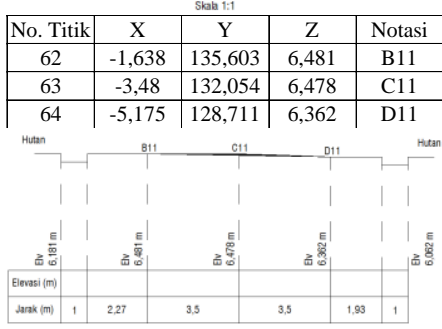

CROSS B11-D11

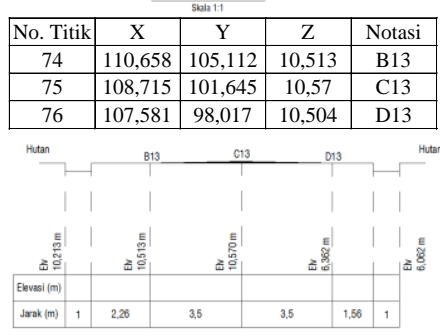

CROSS B13-D13

\begin{tabular}{|c|c|c|c|c|}
\hline No. Titik & $\mathrm{X}$ & $\mathrm{Y}$ & $\mathrm{Z}$ & Notasi \\
\hline 84 & 70,864 & 126,416 & 7,475 & $\mathrm{~B} 15$ \\
\hline 85 & 68,377 & 123,578 & 7,675 & $\mathrm{C} 15$ \\
\hline 86 & 65,796 & 120,368 & 7,794 & D15 \\
\hline
\end{tabular}

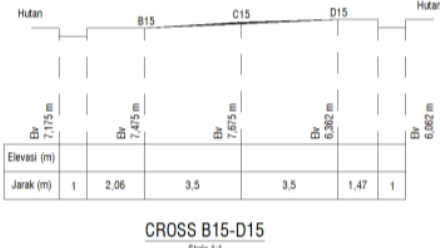

Data Pengkuran Long Section dan Cross Section Lokasi Penelitian II :
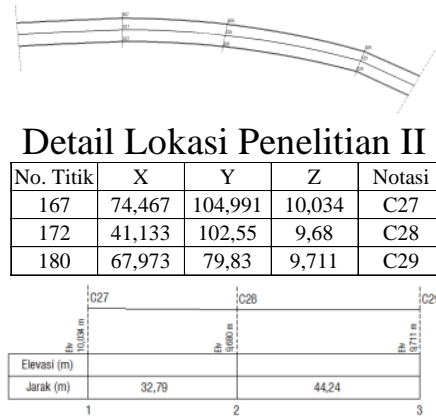

LONG SECTION C27 - C29

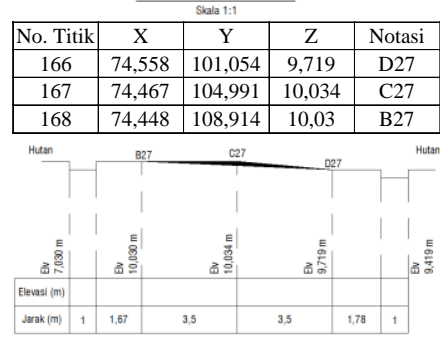

CROSS B27-D27

\begin{tabular}{|c|c|c|c|c|}
\hline No. Titik & $\mathrm{X}$ & $\mathrm{Y}$ & $\mathrm{Z}$ & Notasi \\
\hline 171 & 40,259 & 106,279 & 9,963 & $\mathrm{~B} 28$ \\
\hline 172 & 41,133 & 102,55 & 9,68 & $\mathrm{C} 28$ \\
\hline 173 & 41,869 & 98,777 & 9,289 & D28 \\
\hline
\end{tabular}



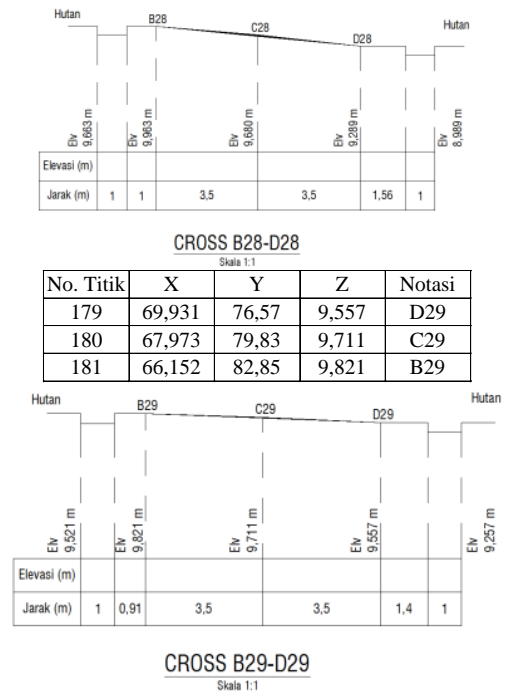

Data Pengkuran Long Section dan Cross Section Lokasi Penelitian III :

Detail Lokasi Penelitian III

\begin{tabular}{|c|c|c|c|c|}
\hline No. Titik & X & Y & Z & Notasi \\
\hline 220 & $-90,647$ & 123,073 & 7,132 & C35 \\
\hline 230 & $-136,83$ & 125,642 & 6,627 & C36 \\
\hline 248 & $-180,912$ & 135,714 & 5,805 & C38 \\
\hline
\end{tabular}

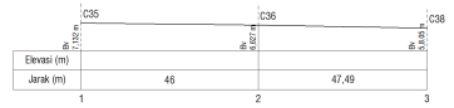

LONG SECTON C35- C38

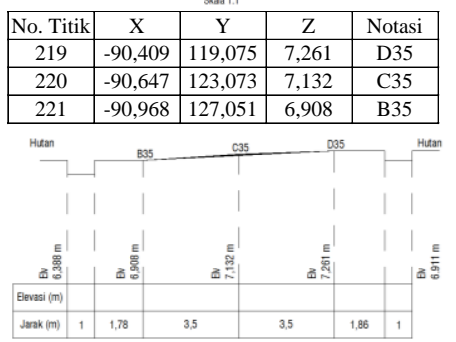

CROSS B35-D35

\begin{tabular}{|c|c|c|c|c|}
\hline No. Titik & $\mathrm{X}$ & $\mathrm{Y}$ & $\mathrm{Z}$ & Notasi \\
\hline 229 & $-137,238$ & 121,754 & 6,691 & D36 \\
\hline 230 & $-136,83$ & 125,642 & 6,627 & C36 \\
\hline 231 & $-136,274$ & 129,619 & 6,338 & B36 \\
\hline
\end{tabular}

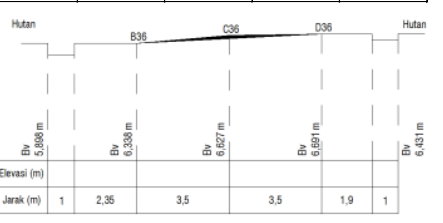

CROSS B36-D36

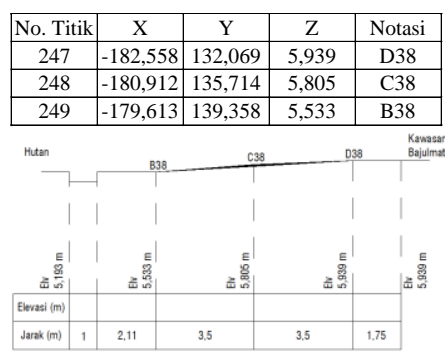

CROSS B38-D38
Data Pengkuran Long Section dan Cross Section Lokasi Penelitian IV :

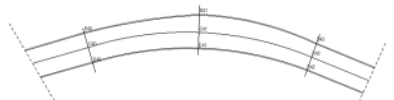

Detail Lokasi Penelitian IV

\begin{tabular}{|c|c|c|c|c|}
\hline No. Titik & X & Y & Z & Notasi \\
\hline 282 & $-332,366$ & 162,339 & 6,665 & C40 \\
\hline 292 & $-365,618$ & 158,598 & 9,484 & C41 \\
\hline 297 & $-390,818$ & 146,184 & 10,944 & C42 \\
\hline
\end{tabular}

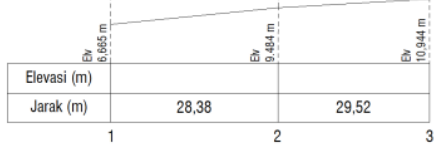

LONG SECTION C40 - C42
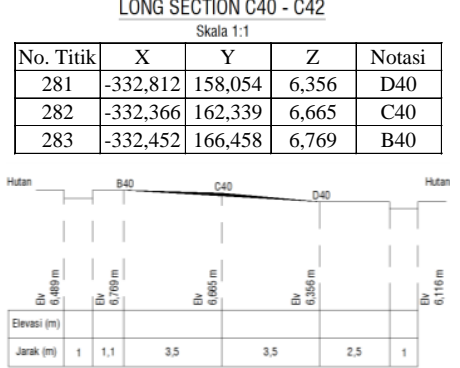

CROSS B40-D40

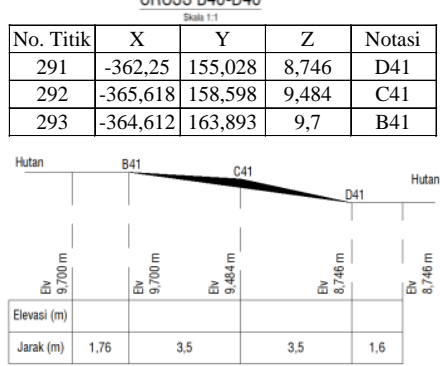

CROSS B41-D41
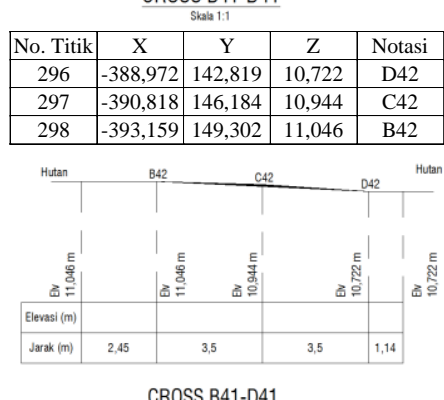

CROSS B41-D41

PERHITUNGAN GEOMETRIK (CURVE HORISONTAL)

$\mathrm{LC}=\pi \mathrm{R} \Delta / 180^{\circ}$

$\mathrm{C}=2 \mathrm{R} \sin (\Delta / 2)$

$\mathrm{T}=\mathrm{R} \tan (\Delta / 2)$

$\mathrm{ES}=\mathrm{T} \tan (\Delta / 4)$

$\mathrm{V}=70-120 \mathrm{~km} / \mathrm{jam}$, diambil angka 70 $\mathrm{km} / \mathrm{jam}$ (rencana kecepatan minimum)

$\mathbf{R} \quad=\mathbf{V}^{2} / 127\left(\mathbf{e}_{\text {maks }}+\mathbf{f}_{\text {maks }}\right) \ldots(10)$

$\mathrm{e}_{\text {maks }}=0,10 \mathrm{~m} / \mathrm{m} ; \quad \mathrm{f}_{\text {maks }}=0,140$

Maka :

$\mathrm{R} \min =70^{2} / 127(0,10+0,140)$

$\mathrm{R} \min =160,761$ meter $=165$ meter 


\section{Curve Horisontal (Lokasi Penelitian I)}

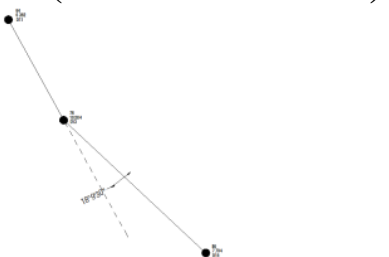

Sudut Horizontal Lokasi Penelitian I

$\Delta_{1} \quad=18^{\circ} 09^{\prime} 30^{\prime}$

Maka : $\mathrm{LC}_{\text {analisa }}$

$\mathrm{LC}_{1}=52,292$ meter

$\mathrm{C}_{1}=52,074$ meter

$\mathrm{T}_{1}=367$ meter

$\mathrm{ES}_{1}=2,093$ meter

Hasil penelitian Curve Horizontal : Data panjang (lengkunan dilapangan) $\mathrm{LC}$ lapangan $=$ 75.63 meter, dan $\mathrm{LC}_{\text {analisa }}=52,292$ meter.

Curve Horisontal (Lokasi Penelitian II)

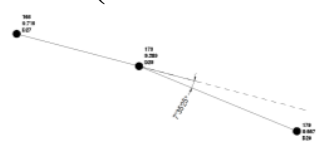

Sudut Horizontal Lokasi Penelitian II

$$
\Delta_{2} \quad=7^{\circ} 35 \text { ' 25' }
$$

Maka : $\mathrm{LC}_{\text {analisa }}$

$\mathrm{LC}_{2}=21,858$ meter

$\mathrm{C}_{2}=21,842$ meter

$\mathrm{T}_{2}=10,945$ meter

$\mathrm{ES}_{2}=0,363$ meter

Hasil penelitian Curve Horizontal : Data panjang (lengkunan dilapangan) $\mathrm{LC}$ lapangan $=$ 77,030 meter, dan $\mathrm{LC}_{\text {analisa }}=21,858$ meter.

Curve Horisontal (Lokasi Penelitian III)

$$
\text { . }
$$

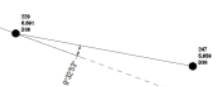

Sudut Horizontal Lokasi Penelitian III $\Delta_{3}=9^{\circ} 32^{\prime}$ 53"

Maka : LC analisa

$\mathrm{LC}_{3}=27,496$ meter

$\mathrm{C}_{3}=27,465$ meter

$\mathrm{T}_{3}=13,780$ meter

$\mathrm{ES}_{3}=0,574$ meter

Hasil penelitian Curve Horizontal : Data panjang (lengkunan dilapangan) $\mathrm{LC}$ lapangan $=$ 93,493 meter, dan $\mathrm{LC}_{\text {analisa }}=27,496$ meter.

Curve Horisontal (Lokasi Penelitian IV)

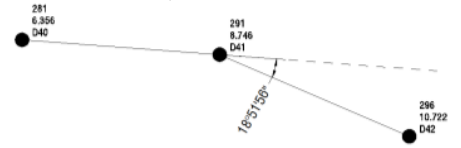

Sudut Horizontal Lokasi Penelitian IV

$\Delta_{4}=18^{\circ} 51$ ' 56"

Maka : LC ${ }_{\text {analisa }}$

$\mathrm{LC}_{4}=54,329$ meter

$\mathrm{C}_{4}=54,084$ meter

$\mathrm{T}_{4}=27,413$ meter
$\mathrm{ES}_{4}=2,262$ meter

Hasil penelitian Curve Horizontal : Data panjang (lengkunan dilapangan) $\mathrm{LC}$ lapangan $=$ 57,89 meter, dan $\mathrm{LC}_{\text {analisa }}=54,329$ meter.

Dikarenakan dari semua perhitungan LC lapangan lebih panjang dari LC analisa maka tidak perlu adanya perbaikan rute horisontalnya.

\section{PERHITUNGAN GEOMETRIK (CURVE VERTIKAL)}

Pada perhitungan curve vertikal dari ke empat lokasi penelitian diambil lokasi penelitian IV untuk dianalisa curve vertikalnya karena memiliki kelandaian vertikal yang kurang memadai.

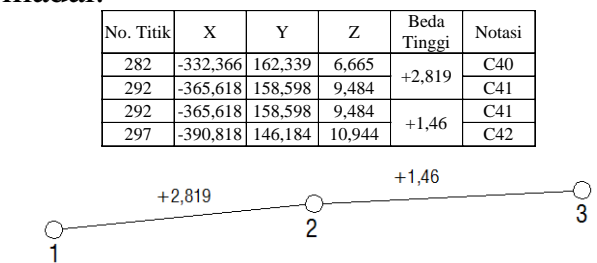

Beda tinggi Lokasi Penelitian

$$
\begin{aligned}
\mathrm{g} 1(\%)= & \frac{E l v \cdot P V I-E l v . P L V}{\frac{1}{2} L V} \times 100 \ldots \ldots \ldots(11) \\
= & (2,819 / 28,38) 100=0,099331= \\
& 9,9331 \% \\
\mathrm{~g} 2(\%)= & \frac{\text { Elv.PTV-Elv.PVI}}{\frac{1}{2} L V} \times 100 \ldots \ldots(12) \\
= & (1,46 / 29,52) 100=0,049458= \\
& 4,9458 \% \\
\mathrm{~A} \quad & \mathrm{~g} 2-\mathrm{g} 1=0,049458-0,099331=- \\
& 0,049873
\end{aligned}
$$

$\mathrm{EV} \quad=\frac{A}{8} \mathrm{LV}=(-0,049873 / 8) 57,9$ $=-0,36096$ meter

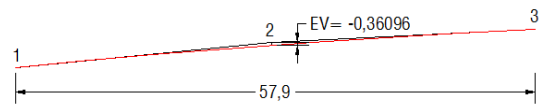

Penentuan EV Lokasi Penelitian IV Hasil penelitian curve vertikal : dari hasil perhitungan Pergeseran Verikal (EV) sebesar 0,36096 meter, maka di titik 2 adalah galian sedalam (- 0,36096 meter).

KOORDINASI ALINYEMEN VERIKAL DAN ALINYEMEN HORIZONTAL

Kombinasi Vertikal Analisa dan Horizontal Analisa

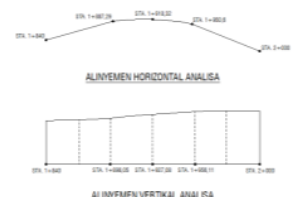

Kombinasi Vertikal Analisa dan Horizontal Lapangan 


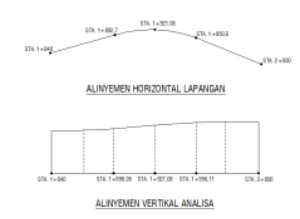

Kombinasi Vertikal Lapangan dan Horizontal Analisa

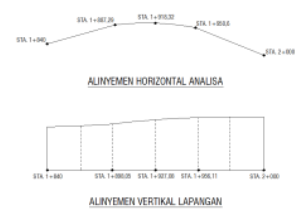

Kombinasi Vertikal Lapangan dan Horizontal Lapangan

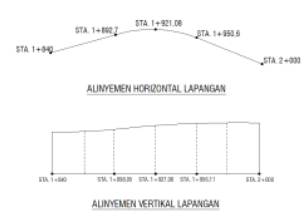

Dari hasil semua kombinasi alinyemen vertikal dan alinyemen horizontal disimpulkan semua bahwa kombinasi tersebut sudah memenuhi ketentuan.

\section{INVENTARISASI JALAN}

\section{Marka Jalan}

Menurut Peraturan Menteri Perhubungan Republik Indonesia Nomor PM 34 Tahun 2014 Tentang Marka Jalan pasal 17 ayat (1) sampai ayat (3) sudah dijelaskan tentang fungsi, jenis, dan ukuran marka. Pada pasal 60 ayat (1) dijelaskan tentang penempatan marka membujur berupa garis utuh.

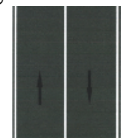

Bentuk dan warna marka membujur dilapangan

Dimensi marka dilapangan dengan peraturan diatas telah sesuai yaitu $12 \mathrm{~cm}$, dan berupa marka membujur garis utuh jadi tidak perlu adanya perbaikan marka.

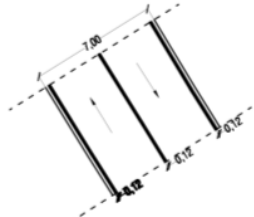

\section{Lampu Penerangan Jalan}

Menurut Peraturan Menteri Perhubungan Republik Indonesia Nomor PM 27 Tahun 2018 Tentang Alat Penerangan Jalan pasal 46 huruf (a) jalan arteri, ketinggian tiang paling rendah 9.000 (sembilan ribu) milimeter. Pada pasal 101 penempatan dan pemasangan alat penerangan jalan sebagaimana dimaksud dalam Pasal 99 disebelah kiri dan/ atau kanan jalan menurut arah lalu lintas pada jarak paling sedikit 600 (enam ratus) milimeter diukur dari bagian terluar bangunan konstruksi alat penerangan jalan ke tepi paling kiri dan/ atau kanan jalur ruang lalu lintas atau kerb.
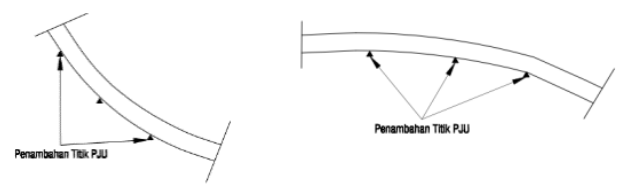

Lokasi penelitian I Lokasi penelitian II

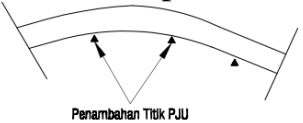

Lokasi penelitian IV

\section{Rambu-Rambu Lalu Lintas}

Menurut Peraturan Menteri Perhubungan Republik Indonesia Nomor PM 13 Tahun 2014 Tentang Rambu Lalu Lintas pasal 7 ayat (1) menjelaskan fungsi rambu peringatan. Pada pasal 8 disebutkan macam-macam rambu peringatan, sedangkan pasal 35 menjelaskan ketentuan letak rambu dan pasal 36 menerangkan ketentuan tinggi rambu. Pada pasal 37 menyatakan ketentuan kecepatan rencana sesuai dimensi rambu, sedangkan pasal 39 menjelaskan tentang jarak rambu dengan titik awal tikungan.

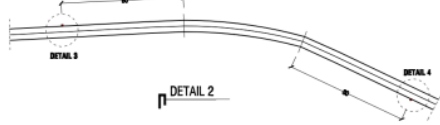

Detail perencanaan rambu

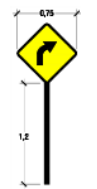

Detail rambu

\section{KESIMPULAN}

1. Nilai DS 2019 sebesar 0,182 (A) adalah kondisi arus bebas dengan kecepatan tinggi dan volume lalu-lintas rendah. Pengemudi dapat memilih kecepatan yang diinginkannya tanpa hambatan. Nilai DS 2039 sebesar $=0,309(\mathrm{C})$ adalah dalam zone harus stabil pengemudi dibatasi dalam memilih kecepatannya.

2. Dalam perencanaan tebal perkerasan lentur menggunakan metode Bina Marga 1987 didapatkan hasil D1 $=5 \mathrm{~cm}($ LASTON), 
D2 $=20 \mathrm{~cm}$ (Batu pecah kelas C), D3 = 40

$\mathrm{cm}$ (Sirtu/Pitrum Kelas C), dan menggunakan metode Bina Marga 2013 didapatkan hasil $\mathrm{AC} \mathrm{WC}=50 \mathrm{~mm}=5 \mathrm{~cm}$, $\mathrm{AC} \mathrm{BC}=280 \mathrm{~mm} 28 \mathrm{~cm}, \mathrm{CTB}=150 \mathrm{~mm}$ $15 \mathrm{~cm}$, LPA kelas $\mathrm{A}=150 \mathrm{~mm}=15 \mathrm{~cm}$.

3. Pada perhitungan lengkung horinzontal pada empat lokasi penelitian terdapat perbedaan panjang lengkung lapangan (LC Lapangan) dengan panjang lengkung analisa (LC Analisa), adapun perbedaannya sebagai berikut : $\mathrm{LC}_{1}$ lapangan $=75.63$ meter, dan $\mathrm{LC}_{1}$ analisa $=52,29$ meter, $\mathrm{LC}_{2}$ lapangan $=77,030$ meter, dan $\mathrm{LC}_{2}$ analisa $=21,828$ meter, $\mathrm{LC}_{3}$ lapangan $=93,493$ meter, dan $\mathrm{LC}_{3}$ analisa $=$ 27,496 meter, $\mathrm{LC}_{4}$ lapangan $=57,89$ meter, dan $\mathrm{LC}_{4}$ analisa $=54,329$ meter, dikarenakan dari lokasi penelitian I-IV LC lapangan lebih panjang dari LC analisa maka tidak perlu adanya perbaikan rute horisontalnya. Hasil perhitungan curve vertikal didapatkan Pergeseran Verikal (EV) sebesar - 0,36096 meter, maka di titik 2 adalah galian sedalam (- 0,36096 meter). Dalam analisa kombinasi alinyemen vertikal dan alinyemen horizontal sebanyak empat kombinasi dapat disimpulkan bahwa semua kombinasi memnuhhi ketentuan yang seharusnya.

4. Hasil pengambilan data dan perencanaan kelengkapan inventaris jalan pada lokasi penelitian didapatkan hasil Tiang Listrik = 59 titik, Lampu penerangan jalan $=5$ titik, Rambu-rambu lalu lintas $=1$ titik, marka $=$ marka membujur berupa garis utuh. Setelah direncanakan penambahan titik didapatkan hasil Tiang listrik $=59$ titik, Lampu penerangan jalan $=12$ titik (penambahan 7 titik), Rambu-rambu lalu lintas $=9$ titik (penambahan 8 titik), dan marka jalan = marka membujur berupa garis utuh.

\section{REFRENSI}

Departemen Bina Marga, 1987 dan Bina Marga, 2013. Perencanaan Tebal Perkerasan, Jakarta.

Direktorat Jenderal Bina Marga Dep. PU dan TL., 1997. Tata Cara Perencanaan Geometrik Jalan Antar Kota, Jalan No. 038/TBM/1997, Jakarta.

Direktorat Jenderal Bina Marga Dep. PU dan TL., 1976. Peraturan Perencanaan Geometrik Jalan Raya No. 13/1970, Badan Penerbit PU, Jakarta.

MKJI, 1997, Jakarta.

Menteri Perhubungan R.I., 2014. Peraturan Menteri Perhubungan Republik Indonesia No. PM 13 tahun 2014 Tentang Rambu Lalu Lintas, Badan Penerbit Menteri Perhubungan, Jakarta.

Menteri Perhubungan R.I., 2014. Peraturan Menteri Perhubungan Republik Indonesia No. PM 34 tahun 2014 Tentang Marka Jalan, Badan Penerbit Mentri Perhubungan, Jakarta. Menteri Perhubungan R.I., 2018. Peraturan Menteri Perhubungan Republik Indonesia No. PM 27 tahun 2018 Tentang Alat Penerangan Jalan, Badan Penerbit Menteri Perhubungan, Jakarta.

Galih Alif Maulana, 2018. Perencanaan Tebal Perkerasan dan Geometrik JLS Jember, Tugas Akhir, Unmuh Jember.

Fajar Dwi Mulyono, 2018. Evaluasi Geometrik-Kinerja dan Perkerasan Pada Jalan Raya Baluran (Studi Kasus Jalan Raya Bajulmati - Wongsorejo), Tugas Akhir, Unmuh Jember.

S. Hendratingsih.S, 1986. Stake Out Jalan, ITB. Bandung. 